\title{
ОСОБЛИВОСТІ КОМУНІКАТИВНОЇ МЕДІАКОМПЕТЕНТНОСТІ СУЧАСНИХ ПСИХОЛОГІВ - СТУДЕНТІВ І ПРАКТИКІВ
}

\author{
Тетяна Пономаренко \\ аспірантка кафедри політичної психології та міжнародних відносин \\ Національний педагогічний університет імені М. П. Драгоманова \\ 01601, Україна, м. Київ, вул. Пирогова, 9 \\ solovei24081994@gmail.com, https://orcid.org/0000-0003-0949-1611
}

\section{Анотація}

В статті розкрито результати теоретичного та емпіричного дослідження комунікативної медіакомпетентності майбутнього психолога. Уточнено зміст понять «комунікативна компетентність психолога» і «комунікативна медіакомпетентність» психолога та визначено структурні компоненти комунікативної медіакомпетентності майбутнього психолога (когнітивний, емоційний, поведінковий, медіакомпетентність, що містить технічні (цифрові), психологічні та маркетингові ЗУН). Емпіричне дослідження було проведено в період з 2019 по 2020 рік. У ньому взяли участь дві вибірки: психологи-практики $(\mathrm{n}=62)$ та студентипсихологи 3-6 курсів навчання $(\mathrm{n}=277)$. Нами був підібраний банк методик, який дозволив оцінити й порівняти рівень розвитку комунікативної медіакомпетентності психологівпрактиків і студентів-психологів: «Методика оцінки комунікативних та організаторських здібностей (КОЗ-2)» і авторська анкета для дослідження професійної медіакомпетентності психолога «Професійна медіакомпетентність психолога». Встановлено, що лише 7\% психологів-практиків і третина студентів-психологів мають низький рівень комунікативної компетентності особистості; третя частина практикуючих психологів і майже половина майбутніх практичних психологів продемонстрували середній рівень комунікативної компетентності особистості; 66\% психологів і п'ята частина студентів показали високий рівень комунікативної компетентності особистості. 3\% психологів та третя частина студентів мають низький рівень організаторських здібностей; більша половина фахівців і $43 \%$ майбутніх психологів-практиків виявили середній рівень розвитку організаторських здібностей; третина психологів і п'ята частина студентів-психологів виявили високий рівень розвитку організаторських здібностей. Більшість (81\%) психологів і третина студентів (34\%) показали високий і середній рівні розвитку професійної медіакомпетентності. Також розроблено психолого-педагогічні рекомендації щодо розвитку професійної комунікативної медіакомпетентності майбутніх психологів. Перспективи подальшої роботи вбачаємо в дослідженні психологічних чинників розвитку комунікативної медіакомпетентності практичних психологів.

Ключові слюва: комунікація, комунікативна медіакомпетентність психолога, комунікативні здібності, медіакомпетентність, студенти-психологи.

\section{Вступ}

Впродовж останніх півстоліття професійна діяльність психолога невпинно переходила у новий - онлайн формат. Перші неформальні групи, які надавали психологічну допомогу онлайн, з'явилися в 1976 році в США, водночас з появою перших персональних комп'ютерів, 
а популярним онлайн консультування стало вже в 1979 році. В країнах Західної Свропи та США воно набуло значного поширення з середини 90-х років. Починаючи 3 2010-х років, психологи-практики не лише на Заході, але й в країнах пострадянського простору, ведуть професійні акаунти, групи і сторінки психологічного змісту в соціальних мережах, проводять марафони, квести, вебінари, мають власні YouTube та Telegram канали, чати підтримки для клієнтів, проводять Інтернет-консультування тощо. Проте, підкреслимо, що онлайн простір, відкриваючи для фахівця-психолога велике коло можливостей (Zelenin \& Ponomarenko, 2020: 164), одночасно вимагає від нього високого рівня розвитку професійної комунікативної медіакомпетентності. Тому високий рівень розвитку комунікативної медіакомпетентності практичного психолога $\epsilon$ вимогою сучасного суспільства, детермінантою його подальшої професійної успішності та $є$ фундаментом для професійного й особистісного зростання.

Питання діяльності психолога в онлайн просторі вивчали О. Виноградна, В. Зеленін, Ю. Іванеко, С. Лєбєдєва, В. Мицько, Л. Найдьонова, О. Немеш, В. Рубцов, Р. Чанг. Н. Шульце та ін. Проблематику комунікативної компетентності у професійному спілкуванні досліджували зарубіжні (К. Абульханова-Славська, М. Аргайл, Р. Белл, О. Бодалев, Л. Петровська, Ю. Хабермас, Н. Хомський, Дж. Уаймен та ін.) і вітчизняні (Л. Долинська, А. Мудрик, Т. Ханецька та ін.) вчені. Особливості комунікативної компетентності психологів у своїх працях розкрили Л. Войтенко, Р. Даріглазова, О. Корніяка, О. Низовець, Ю. Паскевська, Н. Перегончук та ін. Проблему компетентності в спілкуванні психолога в онлайн досліджували В. Андрієвська, С. Бойко, І. Євченко, Л. Лещенко, С. Лукомська, Т. Пономаренко, К. Фішер, А. Фрід та ін.

Традиційно у психологічній науці під комунікативною компетентністю розуміють сукупність знань, умінь та навичок необхідних особистості для здійснення комунікативної діяльності (Rickheit, 2008). Найбільш поширеним, як у вітчизняній, так і в зарубіжній науці, $\epsilon$ такий підхід до структури комунікативної компетентності особистості (McCroskey, 1982):

- когнітивний компонент пов'язаний зі знаннями мови, граматичних конструкцій, правил спілкування, культури мовлення, етичних норм, тощо (В. Абраменкова, Т. Антипіна, Л. Артемова, А. Бодальов, О. Низовець, Т. Щербакова, В. Ядов та ін.);

- емоційний компонент охоплює емоційну чуйність, емпатію, чутливість до іншого та невербальні прояви (В. Абраменкова, А. Кідрон, О. Низовець, Т. Щербакова та ін.);

- поведінковий компонент відбиває комунікабельність, контактність, комунікативні здібності людини до співпраці, рівень їі комунікативного контролю, спільної діяльності, ініціативність, адекватність у спілкуванні, організаторські здібності, тощо (В. Абраменкова, Л. Артемова, Ю. Смельянов, О. Низовець, Т. Щербакова та ін.).

Когнітивний компонент комунікативної компетентності фахівця починає формувати ще в школі на уроках мови, літератури, етики та розвивається у продовж життя. Емоційний компонент $\epsilon$ частиною загального емоційного інтелекту людини i закладається ще 3 дитинства та розвивається все життя. Поведінковий компонент комунікативної компетентності психолога активно починає розвиватися на етапі навчання у вузі, відповідно до вимог і специфіки майбутньої професійної діяльності.

Відповідно, високий рівень розвитку комунікативної компетентності зумовлює ряд особистісних детермінант, серед яких (Низовець, 2010: 132):

- самоконтроль та саморегуляція у спілкуванні;

- прагнення до постійного самопізнання і професійного вдосконалення;

- гуманістична спрямованість особистості; 
- розвинута рефлексія та емпатія, емоційна чутливість;

- толерантність, відкритість, доброзичливість, товариськість, комунікабельність;

- поінформованість - наявність знань про культурні норми спілкування;

- відсутність агресивної позиції;

- н низький рівень конфліктності та тривожності.

Відтак, комунікативна компетентність фахівців, які працюють у системі «людиналюдина» - це конкретні знання, уміння і навички, що необхідні їм для практичного використання у професійній діяльності (В. Андрісвська, І. Зимняя, Л. Петровська, Г. Почепцов, Дж. Равен та ін.). Комунікативна компетентність практичного психолога - це складно-організоване професійно-особистісне утворення, що детермінує професійне становлення майбутніх психологів: формує їх готовність і здатність ефективно вирішувати комунікативні завдання, що виникають при виконанні різних видів професійної діяльності (психодіагностичної, просвітницької, консультативної, психокорекційної, розвивальної, рекламної) (Войтенко, 2011). Тобто, це сукупність знань і вмінь практичного психолога, які необхідні йому для реалізації успішної професійної комунікації.

Ще на початку 1990-тих років комунікативну медіакомпетентність було визначено, як «компетентність в сприйнятті, створенні та передачі повідомлень за допомогою технічних систем з урахуванням їх специфіки, особливостей та обмежень, яка заснована на здатності до медіадіалогу з людьми» (Шаріков, 1990: 64). Так, формування структури комунікативної медіакомпетентності психолога відбувається за рахунок додаткових знань і вмінь (Андрієвська, 2014: 182), а саме:

- технічні (цифрові) знання і навички для роботи в онлайн просторі - це обізнаність у сфері IКT на рівні впевненого користувача, вміння працювати у соціальних мережах (робити дописи, проводити прямі трансляції, вести бізнес-сторінки, тощо), працювати у вебінарній кімнаті, створювати рекламні банери, тощо;

- психологічні знання та вміння - це навички саморегуляції, самоконтролю, самомотивації, налаштування себе і глядачів (клієнтів) на певний лад, вміння проявляти терпимість стосовно ненормативної поведінки відвідувачів Інтернету - «тролів» й «хейтерів», які залишають гнівні, зневажливі та часто нецензурні коментарі до публікацій чи в прямому ефірі, на вебінарі, розуміти проблеми клієнта в умовах обмежених комунікативних засобів в Інтернеті (відсутність невербальної інформації), тощо;

- маркетингові знання і вміння - навички SMM діяльності, розуміння портрету цільової аудиторії, навички створення «воронки продажів», вміння зацікавити клієнта, навички продаж та ведення переговорів тощо (Zelenin \& Ponomarenko, 2020: 166).

Тому до традиційних компонентів комунікативної компетентності особистості (когнітивний, емоційний, поведінковий) додається четвертий - медіакомпетентність, яка і складається з технічних (цифрових), психологічних і маркетингових знань та вмінь фахівця. А професійна медіакомпетентність практичного психолога - це «сукупність його мотивів, знань, умінь, здібностей (показники: мотиваційний, інформаційний, методичний, діяльнісний, креативний), що сприяють його професійній діяльності» (Федоров, 2010: 25).

Отож, комунікативну медіакомпетентність практичного психолога доцільно розуміти, як сукупність знань, умінь і навичок, що необхідні для успішної комунікації в медіапросторі 3 метою реалізації професійних цілей.

Мета дослідження полягала в теоретичному та емпіричному вивченні комунікативної медіакомпетентності психологів-практиків і майбутніх психологів. 
Завдання дослідження: 1) уточнити зміст i встановити структуру феномена «комунікативна меіакомпетентність практичного психолога»; 2) емпірично виміряти i порівняти рівні розвитку комунікативної медіакомпетентності психологів-практиків i студентів-психологів; 3) розробити психолого-педагогічні рекомендації для майбутніх практичних психологів щодо розвитку їх комунікативної медіакомпетентності.

\section{Методи і методи дослідження}

Емпіричне дослідження було проведено в період з 2019 по 2020 рік. У ньому взяли участь дві вибірки: 1) психологи-практики (n=62) (шкільні психологи та психологи дитячих садочків, психотерапевти, коучі, арт-терапевти, тренери і консультанти); 2) студентипсихологи 3-6 курсів навчання $(\mathrm{n}=277)$. Підібраний банк методик дозволив оцінити рівень розвитку комунікативної медіакомпетентності психологів-практиків і студентів-психологів. Оскільки комунікативну компетентність фахівця визначають його комунікативні здібності (Андрієвська, 2014), то за допомогою «Методики оцінки комунікативних та організаторських здібностей (КО3-2)», ми дослідили рівень розвитку комунікативних та організаторських здібностей респондентів (а саме когнітивну, поведінкову й емоційну складові комунікативної медіакомпетентності психологів). А також за допомогою авторської анкети «Професійна медіакомпетентність психолога» вивчили рівень розвитку професійної медіакомпетентності (четверта складова комунікативної медіакомпетентності психолога). Анкета складається з 20 запитань і має таку інструкцію.

«Інструкція: Прочитайте запропоновані запитання та дайте на них відповідь «так» або «ні». А також в запитаннях №1, 15, 19, 20 оцініть від 1 до 10 ступінь прояву у Вас навички про яку йдеться в запитанні».

Текст опитувальника

1. Чи використовуєте Ви акаунти у соціальних мережах у професійній діяльності? Якщо так, то оцініть як часто (де 1 це дуже рідно, а 10 регулярно).

2. Чи користуєтесь Ви Skype або іншими месенжерами у професійній діяльності (для індивідуальних консультацій з клієнтом)?

3. Чи відвідуєте Ви онлайн заходи (майстер-класи, вебінари, тощо)?

4. Чи проводите Ви онлайн заходи (майстер-класи, вебінари, тощо)?

5. Чи проводили Ви онлайн-конференції?

6. Чи практикуєте Ви навчання онлайн?

7. Чи ведете Ви групи або бізнес сторінки професійного змісту?

8. Чи вмієте Ви знімати та монтувати відео на професійні теми?

9. Чи вмієте Ви створювати рекламні банери, обробляти фото чи картинки?

10. Чи вмієте Ви створювати презентації?

11. Чи вмієте Ви створювати Google форми?

12. Чи вмієте Ви створювати сайти (лендінги)?

13. Чи ведете Ви свій ҮouTube канал?

14. Чи вмієте Ви вести чати підтримки для своїх клієнтів у месенжерах (WhatsApp, Viber, Telegram, тощо)?

15. Чи маєте Ви чіткі уявлення про свою цільову аудиторію (хто Ваш клієнт)

16. Чи володієте Ви знаннями і навичками SMM маркетингу? Якщо так, оцініть від 1 до 10 (де 1 - маю мінімальні уявлення, а 10 - володію на високому рівні).

17. Чи відоме Вам поняття «воронка продажів»? 
18. Чи маєте Ви лінійку своїх продуктів?

19. Чи легко Вам вдається вийти в прямий ефір до своїх клієнтів (на вебінарі, в соціальних мережах, тощо). Якщо так, то оцініть від 1 до 10, (де 1 - занадто важко, а 10 роблю це з легкістю та задоволенням).

20. Чи вдається Вам управлятися 3 негативними коментарями на свою адресу в соціальних мережах та на онлайн заходах? Якщо так, то оцініть від 1 до 10, (де 1 - майже не управляюсь, а 10 - вдається повною мірою).

\section{Результати та дискусії}

Емпірично досліджено комунікативні та організаторські здібності, а також професійну медіакомпетентність сучасних психологів - студентів і практиків. Спершу за допомогою Тесту «КОЗ-2» було встановлено рівень розвитку комунікативних здібностей психологівпрактиків і студентів-психологів. Отримані кількісні дані подано на рис. 1.

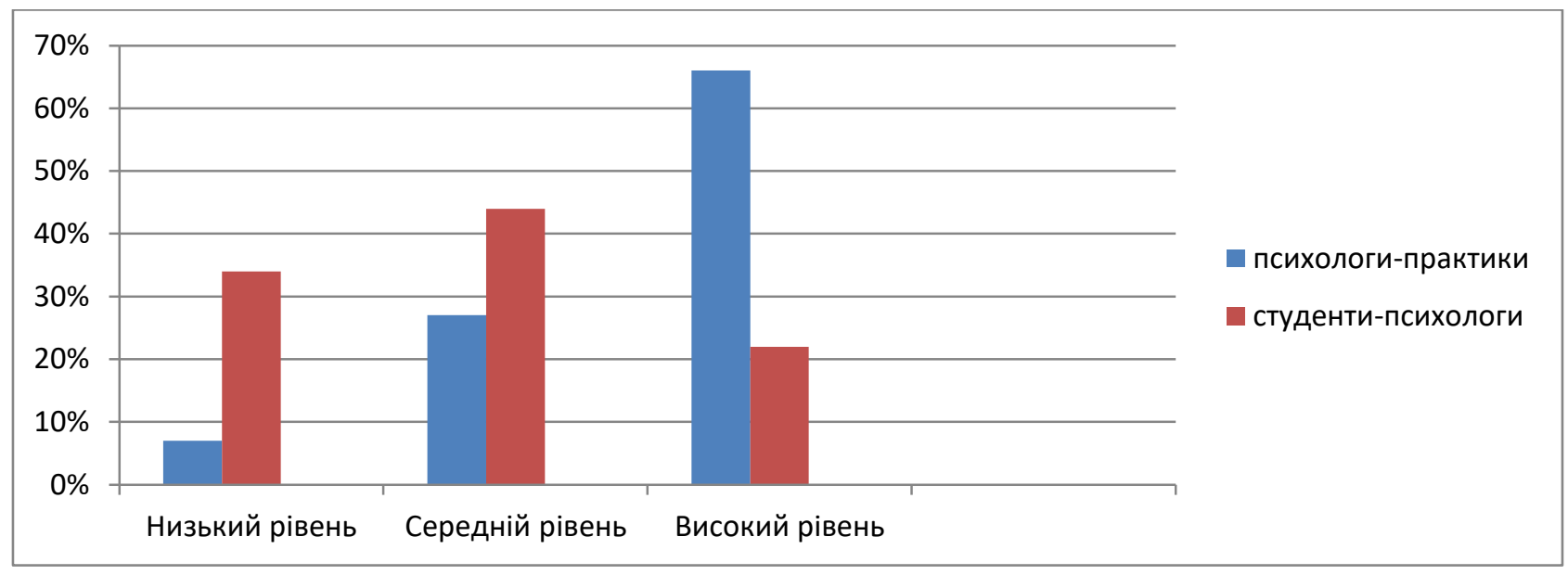

Рис. 1. Зіставлення показників рівнів комунікативних здібностей психологів-практиків і студентів-психологів за методикою КОЗ-2 (у\%)

Проаналізувавши дані рис. 1, ми отримали такі результати. Низький рівень розвитку комунікативних здібностей мають 7\% (4 особи) психологів та 34\% (94 особи) студентів. Такі особи мають складнощі у спілкуванні. В них виникають труднощі у висловлюванні власної думки, їм складно створювати нові контакти, спілкуватися 3 новими людьми. Ці студенти і психологи, зазвичай, не виступають публічно, не проводять прямих ефірів в соціальних мережах, вебінарів, групових тренінгів і майстер-класів. Середній рівень розвитку комунікативних здібностей виявлено в 27\% (16 осіб) психологів і 44\% (121 особа) студентів. Ці особи вміють формулювати і висловлювати власну думку, іноді мають труднощі в діловому спілкуванні, виступають публічно, але для не великої аудиторії слухачів. Вони публікують дописи у соціальних мережах, але це переважно записані відео, а не живі ефіри. Високий рівень розвитку комунікативних здібностей продемонстрували 66\% (40 осіб) психологів та 22\% (61 особа) студентів. Таких людей називають «майстрами слова». Їх мова не лише лаконічна, влучна, а й креативна. Вони легко знайомляться, ведуть ефективні співбесіди на переговорах та із задоволенням виступають для широкого кола глядачів. Такі фахівці часто є ведучими великих тренінгів, майстер-класів чи вебінарів. Вони регулярно проводять прямі ефіри, марафони. $Є$ спікерами онлайн чи офлайн конференцій. 
Підсумовуючи, зазначимо, що практикуючі психологи мають значно вищі показники рівня розвитку комунікативної компетентності, порівняно з майбутніми фахівцями. Це в свою чергу, обумовлено досвідом у професійній діяльності, мотивами особистості та постійною мовленнєвою практикою перших і обмеженими можливостями, низьким рівнем мотивації та відсутністю достатньої кількості практики у останніх.

Важливу роль у комунікативній медіакомпетентності практичного психолога відіграють його організаторські здібності. Вони дозволяють фахівцеві не лише розпланувати та організувати свою професійну діяльність, а і поставити чіткі завдання своїм помічникам (при наявності) та організувати роботу клієнтів (учасників тренінгу, вебінару, прямого ефіру, тощо). Тому наступним кроком було діагностування i порівняння рівнів розвитку організаторських здібностей у психологів та студентів. Отримані дані подано на рис. 2.

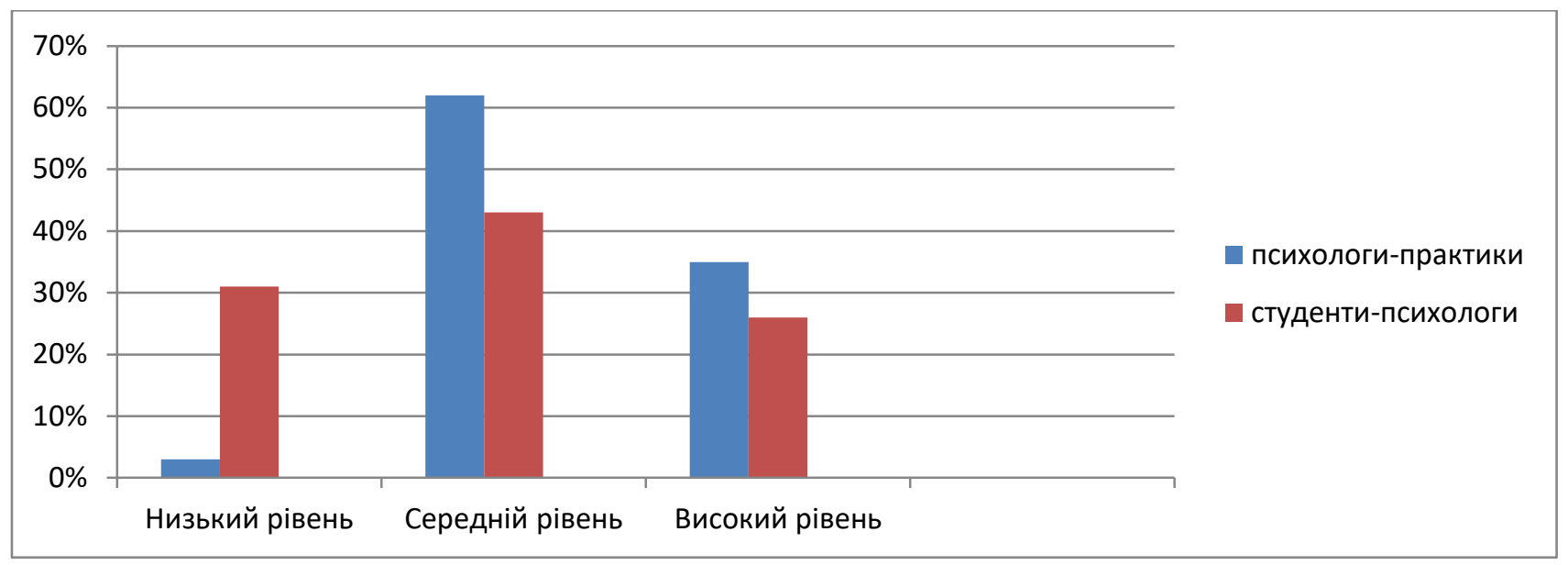

Рис. 2. Зіставлення показників рівнів організаторських здібностей психологівпрактиків і студентів-психологів за методикою КОЗ-2 (у\%)

Як видно з рис. 2, 3\% (2 особи) психологів-практиків та 31\% (86 осіб) студентівпсихологів продемонстрували низький рівень розвитку організаторських здібностей такі люди спонтанні, забудькуваті, їм складно спланувати свій день чи певну діяльність. $62 \%$ (38 осіб) психологів та 43\% (120 осіб) студентів показали середній рівень розвитку організаторських здібностей - вони більш зібрані, відповідальні, вміють організувати свій робочий процес, але іноді потерпають невдач (якщо щось іде не за планом). Тобто їм складно переорієнтуватися і змінити свій графік чи справи. 35\% (22 особи) практикуючих фахівців та $26 \%$ (71 особа) майбутніх психологів мають високий рівень розвитку організаторських здібностей - такі люди з легкістю організовують себе і інших навколо. Вони дуже відповідальні, зібрані, їх дії логічні та раціональні. Таким фахівцям легко вдається створити необхідний психологічний клімат на заходах, організувати публіку, проконтролювати підготовку та хід події (вебінару, майстер-класу, онлайн сесії, тощо).

Отже, з діаграми помітно, що третина студентів-психологів має низький показник розвитку організаторських здібностей, а психологи-практики продемонстрували лише середній і високий рівні розвитку організаторських здібностей. На нашу думку, такі результати можуть бути пов'язані 3 індивідуальними особливостями особистості та 3 відсутністю у студентів необхідної кількості життєвого досвіду. 
Зрештою, ми дослідили рівні професійної медіакомпетентності студентів і психологів за допомогою авторської анкети «Професійна медіакомпетентність психолога». Отримані дані подано на рис. 3.

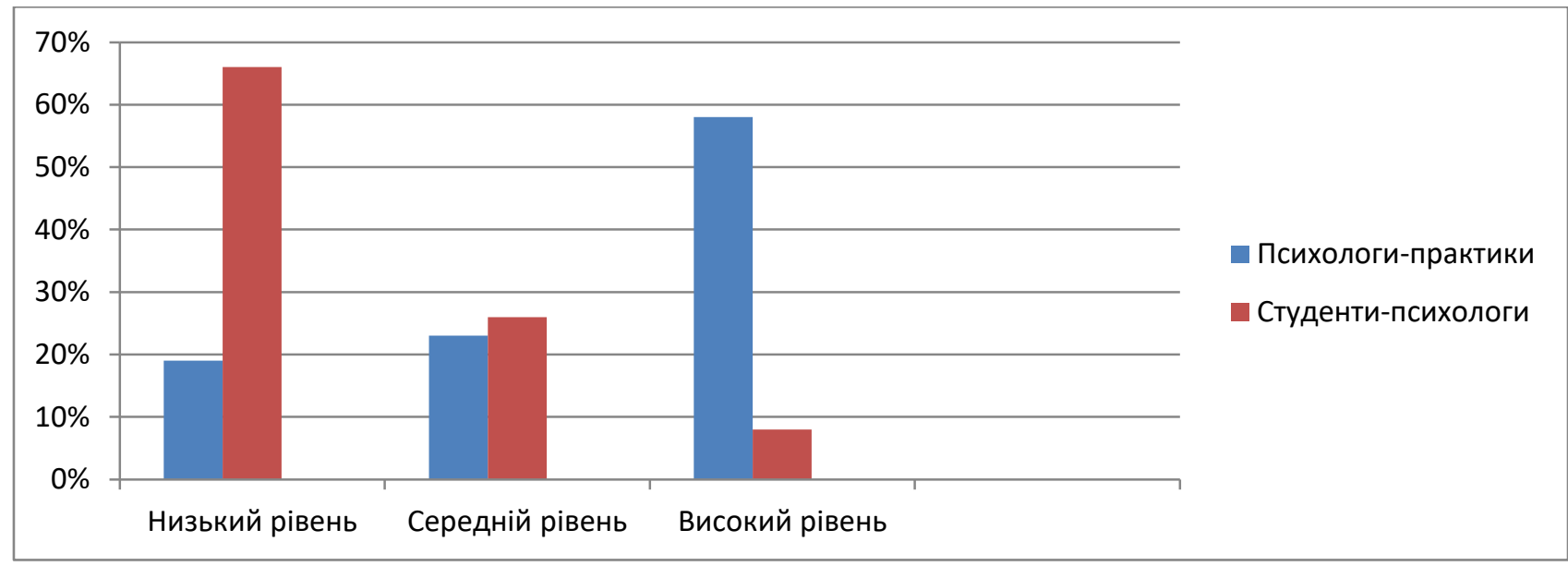

Рис. 3. Зіставлення показників рівнів розвитку професійної медіакомпетентності психологів-практиків та студентів-психологів за авторською анкетою «Професійна медіакомпетентність психолога» (у\%)

Проаналізувавши дані, подані на рис. 3, ми отримали такі результати: 19\% (12 осіб) психологів і 66\% (184) студентів продемонстрували низький рівень розвитку професійної медіа компетентності психолога - вони мають низький рівень технічних, маркетингових та психологічних знань, які необхідні сучасному психологу для успішної професійної діяльності в онлайн просторі. Ці спеціалісти, зазвичай, розміщують поодинокі публікації в соціальних мережах або перепощують дописи своїх колег. Низький показник серед студентів, здебільшого, свідчить про відсутність у них досвіду професійної діяльності у медіапросторі, а відтак, вони володіють достатнім рівнем медіакомпетентності, але на рівні користувача мережі Інтернет. 23\% (14 осіб) практикуючих фахівців та 26\% (72 особи) майбутніх психологів мають середній рівень розвитку професійної медіа компетентності. Вони ведуть сторінки в соціальних мережах, беруть активну участь в онлайн заходах як спікери і як учасники, мають свої групи професійного змісту, але їх діяльність $\epsilon$ епізодичною, не чітко спланованою і не регулярною. 58\% (36 осіб) практикуючих психологів та 8\% (21 особа) студентів-психологів виявили високий рівень професійної медіа компетентності - такі фахівці ведуть регулярну професійну діяльність у медіапросторі: роблять публікації у соціальних мережах, виступають на онлайн заходах, мають власні канали, сайти, чати підтримки для клієнтів, лінійки своїх продуктів та із задоволеннями спілкуються з кліснтами в Інтернет просторі.

Отже, встановлено, що більшість сучасних психологів-практиків мають сформовану професійну медіакомпетентність на середньому і високому рівнях. Виключенням $\epsilon$, зазвичай, психологи державних установ (освітніх закладів, лікарень), які ще не реалізують професійну діяльність в онлайн просторі. Третина студентів-психологів мають сформовану професійну медіакомпетентність на середньому і високому рівні. Це, на нашу думку, пов'язано 3 відсутністю необхідного професійного досвіду для реалізації діяльності в такий спосіб. 
Проаналізувавши отримані результати, ми розробили психолого-педагогічні рекомендаціï з розвитку комунікативної медіакомпетентності майбутніх практичних психологів:

1. Виокреміть час для дослідження профілів психологів-практиків у соціальних мережах, підпишіться на них і відстежуйте їхню діяльність у медіапросторі - це дозволить вам створити власні уявлення про специфіку діяльності психолога в мережі Інтернет та зрозуміти яких саме знань і навичок вам ще не вистачає для реалізації майбутньої професійної діяльності в такий спосіб.

2. Практикуйте навчання онлайн - відвідуйте онлайн заходи практикуючих колег (вебінари, майстер-класи, тощо) - це допоможе вам:

- відслідкувати і освоїти систему відповідно до якої організовуються подібні заходи (як будується вебінар);

- зрозуміти, яким чином забезпечується зворотний зв'язок при такому форматі взаємодії клієнт-психолог;

- проаналізувати, яким чином ведучий вебінару (психолог) формує довіру до себе, мотивує аудиторію, створює необхідних психологічний клімат, працює 3 незадоволеними клієнтами;

- продукувати цікаві ідеї для власних проектів;

- отримувати нові знання та вміння.

3. Цікавтеся новими тенденціями у світі інноваційних технологій - такі знання допоможуть вам обрати максимально зручні для вас та клієнтів способи онлайн взаємодії.

4. По можливості, відвідуйте конференції з маркетингу - там ви зможете оволодіти необхідними SMM-знаннями для успішної професійної діяльності в соціальних мережах та методології розробки електронних курсів.

5. Відвідуйте психологічні тренінги з розвитку ораторської майстерності та навичок ведення курсів в онлайн форматі, зниження тривожності, підвищення емоційного інтелекту, самооцінки, тощо - такі заходи дозволять вам почуватися впевненіше та професійніше у професійній діяльності в онлайн просторі.

6. Знайдіть час для опанування функціоналу додатків, які необхідні вам для розвитку себе як спеціаліста на просторах Інтернету.

- Перш за все це додатки соціальних мереж (Instagram, Facebook, TikTok, Like), які, наразі, пропонують широкий спектр можливостей (обробка фото, обробка та монтаж відео, тощо).

- По-друге, це застосунки, які дозволяють створювати колажі (inCollage, InShot, Story Maker), опрацьовувати фото (InShot, PicsArt, Snapseed), монтувати відео (InShot, Biteables, Adobe Sparkis ), тощо.

- По-третє, це сервіси розсилок, чат-боти, платформи для створення рекламних банерів (Crello, Canva).

- По-четверте, сервіси для організації відеоконференцій (Zoom, Google Hangouts Meet, Skype, Bigbluebutton, YouTube Live, Microsoft Teams) та телефонні месенжери для організації навчання та підтримки клієнтів (Viber, Telegram, Whatsup, Facebook Messenger).

Всі ці знання і навички допоможуть Вам, як сучасному практичному психологу, «іти в ногу 3 новітніми тенденціями», виконувати все власноруч (поки не маєте можливості 
найняти помічника), розробляти привабливий візуал для своїх публікацій і продуктів, розвивати власну комунікативну медіакомпетентність.

\section{Висновки}

Отож, за результатами теоретичного аналізу, уточнено зміст поняття «комунікативна меіакомпетентність практичного психолога»; досліджено і встановлено його структуру, що містить такі компоненти, як: когнітивний, емоційний, поведінковий і медіакомпетентність (сукупність технічних (цифрових), психологічних і маркетингових ЗУН). Комунікативна медіакомпетентність практичного психолога - це сукупність знань, умінь і навичок, які необхідні психологу для успішної реалізації професійної діяльності в онлайн просторі.

За результатами проведеного емпіричного дослідження встановлено, що лише 7\% психологів-практиків і 34\% студентів-психологів мають низький рівень комунікативної компетентності особистості; 27\% психологів і 44\% студентів - середній; $61 \%$ психологів і $22 \%$ студентів - високий. Лише 3\% практиків і 31\% студентів продемонстрували низький рівень розвитку організаторських здібностей; 62\% психологів і 43\% майбутніх психологів середній і $35 \%$ фахівців та $26 \%$ студентів - високий. У більшості сучасних психологівпрактиків (81\%) професійна медіакомпетентність сформована на середньому і високому рівнях. Третина студентів-психологів має сформовану професійну медіакомпетентність на середньому і високому рівнях.

Перспективи подальших досліджень вбачаємо у вивченні психологічних чинників розвитку комунікативної медіакомпетентності майбутніх практичних психологів.

\section{Література}

1. Андрієвська, В.В. (Ред). (2014). Методологічні проблеми трансформації комунікативної компетентності психолога в інформаційному суспільстві. (Монографія). КиївКіровоград : Імекс-ЛТД.

2. Войтенко, Л.М. (2011). Коммуникативная компетентность как детерминанта профессионального становления будущего психолога. (Автореф. дисс. канд. психол. наук). Сочи.

3. Низовець, О. А. (2010). Комунікативна компетентність студентів-психологів як умова успішності професійної діяльності. Науковий часопис НПУ імені М.П. Драгоманова. Серія № 12. Психологічні науки, 30(54), 129-134.

4. Федоров, А.В. (2010). Словарь терминов по медиаобразованию, медиапедагогике, медиаграмотности, медиакомпетентности. Таганрог : Изд-во Таганрог. гос. пед. ин-та.

5. Шариков, А. В. (1990). Медиа образование: мировой и отечественный опыт. Москва : НИИ СО и УК АПН СССР.

6. McCroskey, J.C. (1982). Communication Competence and Performance: A Research and Pedagogical Perspective. Communication Education, 31, 42-54.

7. Rickheit, G. (2008). Handbook of Communicative Competence. Gottingen : Hubert \& Co.

8. Zelenin, V., \& Ponomarenko, T. (2020). Media competence of a future psychologist as a condition of successful professional fulfilment. Modern researches in psychology and pedagogy: Collective monograph. Riga : Izdevnieciba "Baltija Publishing". doi.org/10.30525/978-9934-588-36-5/9 


\section{References}

1. Andriievska, V.V. (Ed.). (2014). Metodolohichni problemy transformatsii komunikatyvnoikompetentnosti psykholoha $v$ informatsiinomu suspilstvi. [Methodological problems of transformation of communicative competence of a psychologist in the information society]. Kyiv-Kirovohrad : Imeks-LTD [in Ukrainian].

2. Voytenko, L.M. (2011). Kommunikativnaya kompetentnost kak determinanta professionalnogo stanovleniya budushchego psikhologa [Communicative competence as a determinant of professional development of a future psychologist]. Extended abstract of Candidate's thesis. Sochi [in Russian].

3. Nyzovets, O.A. (2010) Komunikatyvna kompetentnist studentiv-psykholohiv yak umova uspishnosti profesiinoi diialnosti [Communicative competence of students-psychologists as a condition for success of professional activity]. Naukovyi chasopys NPU imeni M.P. Drahomanova. Seriia № 12. Psykholohichni nauky - Scientific Journal of National Pedagogical Dragomanov University. Series 12. Psychological Sciences, 30(54), 129-134 [in Ukrainian].

4. Fedorov. A.V. (2010) Slovar terminov po mediaobrazovaniyu, mediapedagogike, mediagramotnosti, mediakompetentnosti [Glossary of terms on media education, media pedagogy, media literacy, media competence]. Taganrog: Izd-vo Taganrog. gos. ped. in-ta [in Russian].

5. Sharikov, A.V. (1990) Media obrazovaniye: mirovoy i otechestvennyy opyt [Media education: world and domestic experience]. Moscow : NII SO i UK APN SSSR [in Russian].

6. McCroskey, J.C. (1982). Communication Competence and Performance: A Research and Pedagogical Perspective. Communication Education, 31, 42-54.

7. Rickheit, G. (2008) Handbook of Communicative Competence. Gottingen : Hubert \& Co.

8. Zelenin, V., \& Ponomarenko, T. (2020). Media competence of a future psychologist as a condition of successful professional fulfilment. Modern researches in psychology and pedagogy: Collective monograph. Riga: Izdevnieciba "Baltija Publishing". doi.org/10.30525/978-9934-588-36-5/9 


\title{
PECULIAR FEATURES OF COMMUNICATIVE MEDIA COMPETENCE OF A MODERN PSYCHOLOGIST - STUDENTS AND PRACTITIONERS Tetiana Ponomarenko
}

Postgraduate student of theDepartment of Political Psychology and International Relations

National Pedagogical Dragomanov University

9, Pyrogov Str., Kyiv, Ukraine, 01601

solovei24081994@gmail.com, https://orcid.org/0000-0003-0949-1611

\begin{abstract}
The article highlights the theoretical and empirical study of the communicative media competence phenomenon of a future psychologist. The meanings of the concepts (communicative competence of a psychologist and communicative media competence of a psychologist) are specified. The structural components of the communicative media competence of a future psychologist are determined (cognitive, emotional, behavioral, media competence, which includes technical (digital), psychological and marketing knowledge and skills). The empirical study was conducted in the period from 2019 to 2020 . Two samples participated in the study: psychologists-practitioners $(\mathrm{n}=$ 62) and students-psychologists of 3-6 academic years $(n=277)$. We selected methods that allowed us to assess and compare the developmental level of communicative media competence of psychologists-practitioners and students-psychologists, namely: "Methods of assessing communicative and organizational skills (COS-2)" and the personally designed questionnaire to study the professional media competence of psychologists "Professional media competence". We found out that only $7 \%$ of psychologists-practitioners and a third of students-psychologists have a low level of communicative competence of the individual; a third of practicing psychologists and almost half of future practical psychologists demonstrated an average level of communicative competence of the individual; $66 \%$ of psychologists and a fifth of students showed a high level of communicative competence of the individual. 3\% of psychologists and a third of students have a low level of organizational skills; more than half of specialists and $43 \%$ of future psychologistspractitioners showed an average level of organizational skills development; a third of psychologists and a fifth of students-psychologists showed a high level of organizational skills development. The vast majority $(81 \%)$ of psychologists and only a third of students $(34 \%)$ showed high and average levels of professional media competence. We have also prepared psychological and pedagogical recommendations for the development of professional communicative media competence of future psychologists. We see prospects for further work in the study of psychological factors of the communicative media competence development of practical psychologists.
\end{abstract}

Keywords: communication, communicative media competence of a psychologist, communicative abilities, media competence, students-psychologists.

Подано 01.12.2020

Рекомендовано до друку 21.12.2020 